\title{
Integrating Manufacturing Projects into Mechanical Engineering Programs
}

\author{
Doug Ramers \\ University of North Carolina, Charlotte
}

Students receive limited exposure to manufacturing in most undergraduate Mechanical Engineering programs - yet a significant number of mechanical engineers end up working in manufacturing operations or engineering support. The manufacturing discipline combines knowledge from a variety of subjects, such as statics, strength of materials, thermofluids, systems, electronics, etc., that are typically taught in isolation without considering interactions. Solving most real world problems requires integrating this knowledge. As a result of the evolution of standardized Mechanical Engineering programs, students are typically exposed to only one semester of manufacturing processes. Manufacturing problems are rarely used to teach students how to integrate their new knowledge and develop skills to solve applied problems.

The Society of Manufacturing Engineers Manufacturing Education Plan ${ }^{1}$ defines a set of critical competencies expected of engineering students entering manufacturing industries. The Plan is a result of workshops with automotive, aerospace, electronics, and other industries. Competencies such as project planning and management, communication, problem solving, teamwork, engineering science, and design apply to all organizations where engineers work. Solving manufacturing problems is a good way to develop these and additional competencies in problem identification, prediction, managing ambiguity and trade-offs, decision-making, DFM, product and process design, and materials applications. The multi-disciplinary nature of manufacturing problems requires concurrent engineering and a systems view often missing in problems used to teach basic, discipline-oriented engineering principles. Manufacturing problems help students understand that most of the analytical skills and knowledge they have been acquiring during their engineering education is intended to support physical realization of objects and systems manufactured by real processes with real materials.

This paper describes some approaches undertaken to help students develop the competencies listed above within a traditional Mechanical Engineering program at Gonzaga University. The approaches involve adding hands-on projects to existing manufacturing related courses, enhancing non-manufacturing courses with manufacturing issues and projects, and using manufacturing problems as senior capstone design projects.

\section{Enhancing Manufacturing Related Courses}

In many traditional Mechanical Engineering programs, the only exposure students have to manufacturing is to one manufacturing processes course. This course is often very focused on 
machining and rarely considers DFM or manufacturing systems. Students systematically study the characteristics of various processes but have limited exposure to them in a weekly lab.

Manufacturing involves the conversion of materials into finished products, and the integration of engineering and management knowledge and skills from a range of disciplines. To address the manufacturing competency issues, we enhanced our required Manufacturing Processes course and added a Manufacturing Systems Analysis and Design course.

\section{Manufacturing Processes Course Project Enhancement}

We added projects that required integrated, multidisciplinary problem solving and engineering management skills to our manufacturing processes course in addition to the traditional topics of process characteristics, material properties, and process equipment. Two different approaches were tried. One semester, teams of students designed and developed equipment to demonstrate a manufacturing process without using conventional process equipment. Another semester, teams of students performed redesign for manufacture and built parts that were used to assemble a finished product. During the first half of each semester, labs introduced the students to shop practices. During the rest of the semester, students applied the shop and course knowledge, and learned specialized knowledge, to solve problems unique to their individual projects. The students prepared and presented written proposals and project plans, reports on designs and analysis, monthly progress and problem reports, and mid-term and final oral presentations to develop their communication capabilities. Students worked in teams and had to solve problems in planning and allocating work -- an important skill for their professional careers.

One semester, students developed a demonstration of a manufacturing process without using commercial process dedicated equipment, such as a foundry facility for casting or drawing presses. Simple machining projects were not permitted. The intent was to demonstrate the separation between manufacturing processes and the equipment used to implement them. Some of the processes the students demonstrated included centrifugal casting, pressure thermoforming, plastic molding and metal casting, and deep drawing. After studying their selected processes, the students had to figure out how to provide the forces, heat, fluids, motion, geometry, etc. to the materials they chose for objects used to demonstrate their processes.

One student modified a polishing wheel in the Materials Laboratory to provide centrifugal forces and designed and built the means to hold the mold to the wheel shaft to demonstrate vertical spin casting. Using a vacuum former as a model, a group of students built their own pressure forming system. Another group used silicon rubber to make molds to cast small parts of materials with melting temperatures under $400^{\circ} \mathrm{F}$. They designed and built molds with sprues and runners, machined patterns or used common parts as patterns, and produced small parts designed for the process. They used the Materials Science laboratory furnaces to melt the material for the castings. Another group of students used an old Tinius-Olson tensile testing machine to provide the controlled forces for deep drawing, and experimented with lubricants, forces, and speed to control wrinkling - a common problem in commercial drawing operations.

For the second approach, the students used a solid model of a universal joint described in the tutorial for the Solid Works [5] solid modeling software (see Figure 1), redesigned each part for two different processes, made the parts, and reassembled them into the finished product. Each 
team was responsible for one or more parts. The students did dimensional take-offs of the different parts, and then selected their processes. For example, the frame could have been made by bending a single piece of aluminum or by welding together several flat pieces of steel. The parts had to be appropriately redesigned to fit each process while retaining the appropriate dimensional relationships of the total product. The students selected materials, developed appropriate dimensions and tolerances, and designed and built tooling and fixtures for each of the selected processes. Once the parts were complete, the teams assembled their best parts into the finished functioning product (Figure 1).

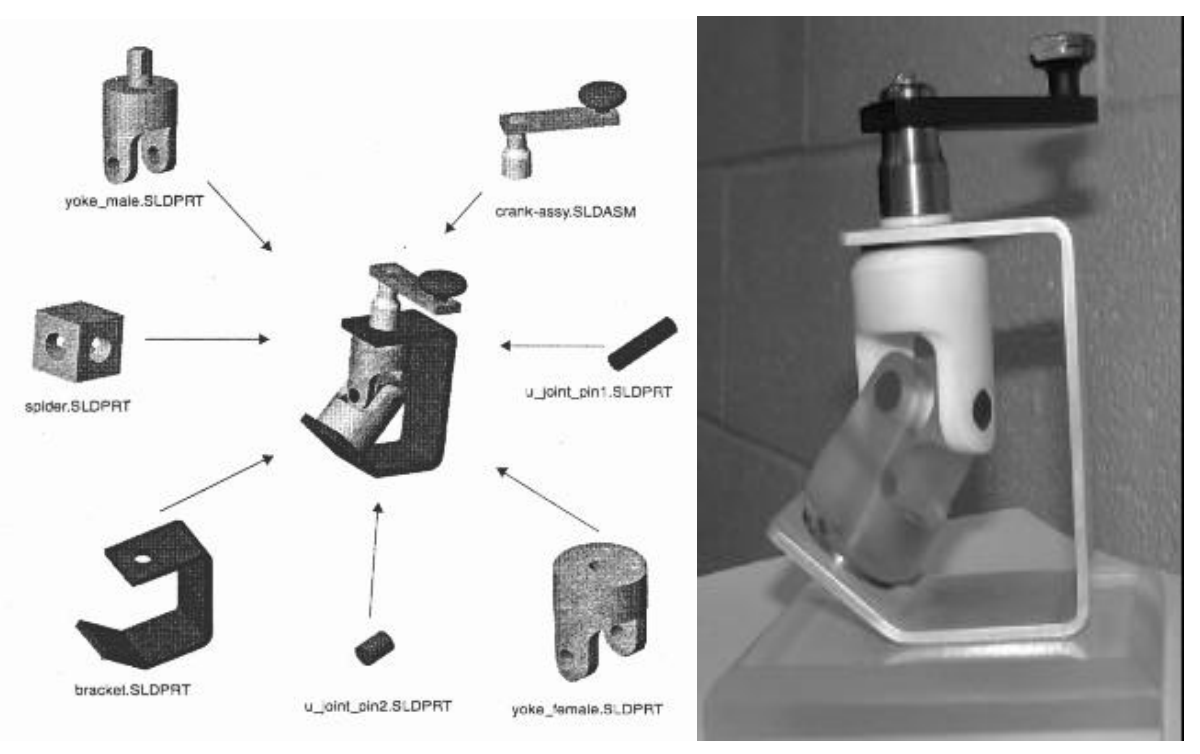

Figure 1 Solid Works Universal Joint Model and Finished Product

\section{Analysis and Design of Manufacturing Systems Elective Course}

Another way to develop professional competencies of Mechanical Engineering students is through special manufacturing elective courses. We provided a special topics course that emphasized the analysis, modeling, and design of manufacturing systems. Most traditional engineering curriculums are weak when it comes to teaching students integration, interfacing, and a systems perspective. In this course, students had to study, discuss, and practice techniques to solve integrated design and manufacturing problems, both individually and as a group, including the design of an entire manufacturing system. Some of the topics covered in the course included:

- $\quad$ Design tools such as process specification, requirements analysis, and QFD

- $\quad$ Concurrent engineering: simultaneous product and process design

- $\quad$ Process planning and group technology

- Manufacturing systems: assembly lines, transfer lines, cellular, just in time, flexible, agile

- $\quad$ Manufacturing planning, scheduling, and control

- $\quad$ Facility layout and materials handling systems

- Statistical process control and inspection

- $\quad$ Computer integrated manufacturing with CAD/CAM 
The primary textbook used was Sule's Manufacturing Facilities ${ }^{2}$, supplemented with materials from other texts in design, quality, CAD/CAM, and industrial guides. The class manufacturing system design project was the production of a head protection system for fighter pilots during ejection, which was being designed for a concurrent Senior Design project. The product consisted of a mechanism to project two composite side guards forward, and an overhead fabric cover to disrupt upward air pressure and lift on the pilot's helmet.

The class of 12 students was divided into two teams, with one member of the Senior Design project team assigned to each, to provide product expertise. Each team developed a manufacturing process and associated system, a production plan, quality plan, and cost estimates to produce a large quantity of the protection systems. The teams presented their work as a competitive proposal and job bid to win the production contract. The instructor was the customer and bid reviewer, and suggested to the students that the group winning the proposal would get an "A" grade for the project, while the other group would get a lesser grade. The proposals were not actually graded this way, but the students were not sure of this until after they turned in their proposals. The competition appeared to motivate students and made their work more interesting. Both proposals were very good and had more detail, such as specific equipment, tolerances, quality and operating plans, and cost estimates, than students typically have to develop for their courses. These are the details that turn concepts and theory into realized products.

\section{Including Manufacturing Projects in Other Courses}

Students take a materials course that is often more materials science than materials engineering, and design or materials oriented elective courses are often a rehash or extension of strength of materials courses. These courses can be modified to incorporate the engineering activities this type of analysis is intended to support - design and manufacturing. A change in perspective in our materials courses and modification of a course on composites gave our mechanical engineering students experiences that helped them develop engineering competencies.

Materials, for mechanical engineers, should be taught from a design and manufacture perspective. The students should understand that they study materials so that they can properly specify them in designs, and that material properties are designed and modified with manufacturing processes to suit the needs of a final product. We incorporated a half-semester project into our materials course in which students were given some materials: aluminum, steel, and copper, and set of desired strength and hardness properties. The students researched and designed appropriate processes, and applied them to the materials to obtain the desired properties. They verified the properties through tensile and hardness testing. The students learned that they could "engineer" a material to obtain a desired set of properties for a product.

We modified a course that had emphasized strength of materials and materials science of composites into a new course called Designing with Polymers and Composites. In the new course, students identified and described problems related to creating a product, developed and integrated design and manufacturing decisions, and learned the fundamental concepts for designing, analyzing, and manufacturing objects with polymers and composite materials. Students selected a plastic product, with at least three to four significant (with respect to requiring design) parts that required assembly, to develop individually throughout the semester. 
The course emphasized the design process from requirements identification through manufacturing planning, and the documentation and communication of design through drawings, reports, and presentations. Two textbooks were used: Plastics: Product Design and Process Engineering $^{3}$ for polymer and composite materials chemistry and characteristics, analysis techniques, design rules, and manufacturing processes; and Engineering Design and Design for Manufacture $^{4}$ for the guided iteration design process and design for manufacturability analysis.

Some of the projects the students chose included an equipment clip for climbers, a composite bow, a bongo drum, a computer keyboard housing, and an industrial battery holder for computers on fork trucks. Considering the full set of design details required, these types of projects are sufficiently complex and difficult to complete in a single semester. In something as simple as a bongo drum, for example, the student had to choose appropriate plastic materials for the drum surface and the body under stress, describe problems and develop approaches to fasten the drum surface to the drum body, make the drum surface replaceable, and provide a means of adjusting the tautness of the drum surface. Designing and analyzing for creep and stress relaxation were significant project issues. The materials and manufacturing processes, design for assembly, and minimizing manufacturing costs also resulted in constraints and tradeoffs for design decisions.

One of the more difficult aspects of this course was presenting information regarding polymers (properties, analysis techniques, design rules, manufacturing processes) and information about the design process in a timely manner to coincide with the different project stages. A carefully laid out syllabus and a project plan (Table 1) was developed, and students had to deliver engineering products on a schedule throughout the semester.

The new course addressed many of the competencies required of engineers and provided technical depth with regards to composite materials and their structural analysis. The students gained valuable experience and understanding of the design process and the concurrent consideration of manufacturing. They learned how to develop and represent customer needs using quality functional deployment and requirement specifications. They used a disciplined design process and analyzed manufacturability, qualitatively and quantitatively, throughout all the phases of design. The students planned and estimated the costs of manufacturing what they had designed, and saw the manufacturing and cost consequences of early design decisions. Finally they had to analyze and design for many simultaneous considerations, such as manufacturability, economics, safety, environmental, customer preferences, and aesthetics.

\section{Introducing Manufacturing Through Capstone Design}

A simple way to introduce mechanical engineering students to manufacturing is through the senior design projects that are required in most programs. At Gonzaga University, all of our Mechanical Engineering Capstone Design projects were provided and sponsored by industries, government agencies, and entrepreneurs. A faculty advisor and industrial liaison were assigned to each project to help guide and work with teams of three to four students. Students investigated their projects and developed a proposal, including preliminary concepts and project plan, during the fall semester. During the spring semester, students were expected to complete their designs, and, if possible, construct a prototype for demonstration on Project Day in late April. The course 
deliverables included the fall interim report and oral presentation in December, and a final report, a display, and oral presentations open to the public in late April.

\begin{tabular}{|c|c|c|}
\hline $\begin{array}{l}\text { Due } \\
\text { Date }\end{array}$ & Activity & Deliverables \\
\hline $9 / 11$ & $\begin{array}{l}\text { Analyze problem \& environment } \\
\text { Identify goals and objectives } \\
\text { Identify conditions \& constrains } \\
\text { Develop approach } \\
\text { Determine feasibility }\end{array}$ & $\begin{array}{l}\text { Preliminary problem assessment } \\
\text { Introduction and background } \\
\text { Problem statement \& objectives } \\
\text { Problem decomposition } \\
\text { Discussion of constraints } \\
\text { Approach: strategy and primary activities }\end{array}$ \\
\hline $9 / 18$ & Develop requirements spec & Requirements Specification (Dixon form) \\
\hline $9 / 30$ & $\begin{array}{l}\text { Develop and select conceptual designs } \\
\text { Develop concept evaluation criteria } \\
\text { Develop and describe } 3+\text { concepts } \\
\text { Evaluate concepts (matrix) and select best }\end{array}$ & $\begin{array}{l}\text { Conceptual Design } \\
\text { Description and decomposition of each concept } \\
\text { Description of evaluation criteria } \\
\text { Evaluation of concepts }\end{array}$ \\
\hline $9 / 30$ & $\begin{array}{l}\text { Develop project plan } \\
\text { Develop project objectives } \\
\text { Identify tasks, milestones, and deliverables } \\
\text { Develop time estimates and schedule }\end{array}$ & $\begin{array}{l}\text { Project Plan } \\
\text { Introduction and objectives } \\
\text { Task descriptions w/estimates } \\
\text { Gantt chart w/milestones }\end{array}$ \\
\hline $9 / 30$ & $\frac{\text { Proposal }}{\text { Assemble previous work into proposal }}$ & $\begin{array}{l}\text { Project Proposal } \\
\text { (see Beer and McMurrey) }\end{array}$ \\
\hline $10 / 30$ & $\begin{array}{l}\text { Configuration design } \\
\text { Develop configuration evaluation matrix } \\
\text { Identify alternative components and features } \\
\text { Identify alternative materials } \\
\text { Generate } 3+\text { configurations } \\
\text { Evaluate configurations and select best } \\
\text { Review/reconceptualize configurations } \\
\text { Refine requirements specification } \\
\text { Decide overall manufacturing processes } \\
\end{array}$ & $\begin{array}{l}\text { Configuration Design } \\
\text { Description of each configuration (including sketches) } \\
\text { Evaluation of configurations } \\
\text { Detailed description (and layout dwgs) of best configuration } \\
\text { Describe manufacturing processes } \\
\text { Manufacturability \& Environmental analysis } \\
\text { Updated Specification }\end{array}$ \\
\hline $11 / 30$ & $\begin{array}{l}\text { Parametric design and analysis } \\
\text { Develop details evaluation matrix } \\
\text { Finalize materials selections } \\
\text { Develop detail feature dimensions } \\
\text { Develop final design specification } \\
\text { Relate design spec to requirements spec } \\
\text { Do manufacturability and environmental analysis }\end{array}$ & $\begin{array}{l}\text { Parametric Design } \\
\text { Introduction } \\
\text { Summary description (physical and functional) } \\
\text { Systems and object drawings or models } \\
\text { Feature descriptions and drawings } \\
\text { Manufacturability \& Environmental analysis } \\
\text { Design specification } \\
\text { Conclusion (relate design specs to requirements) }\end{array}$ \\
\hline $12 / 11$ & $\begin{array}{l}\text { Develop Manufacturing Plan } \\
\text { Identify and describe processes } \\
\text { Identify specific manufacturability rules } \\
\text { Analyze and modify design for manufacturability } \\
\text { Develop process plans and instructions } \\
\text { Estimate time, materials, and equipment }\end{array}$ & $\begin{array}{l}\text { Manufacturing Plan } \\
\text { Introduction } \\
\text { Primary processes } \\
\text { Secondary processes } \\
\text { Process plans } \\
\text { Estimates (time, materials, equipment) }\end{array}$ \\
\hline $12 / 11$ & $\begin{array}{l}\text { Prepare project reports and presentation } \\
\text { Assemble work into cohesive engineering report and } \\
\text { presentation }\end{array}$ & $\begin{array}{l}\text { Report } \\
\text { (see Beer and McMurrey) } \\
\text { Include: Problems statement and objectives, specifications, } \\
\text { project plan, detailed design, mfg. plan }\end{array}$ \\
\hline
\end{tabular}

Table 1 Project Plan and Deliverables

As seniors, students had still not been taught processes to help them plan, organize, and execute engineering projects. They were unfamiliar with requirements, design specifications, generating and evaluating multiple concepts, and the phases of design. I taught my teams a project structure for planning and executing engineering projects. Students used a planning sheet, similar to the one shown previously (Table 1), that listed the project phases, activities, and deliverables, to which students estimated and added schedule dates during preliminary planning. The deliverables included reports for the course due in December and May, and interim documentation throughout the semester that could be compiled into interim and final reports. The interim deliverables helped the students avoid the common "wait until the night before it is due" 
approach. As advisor, my role was that of a hands-off engineering manager who held the students accountable for meeting the schedule that they had set, mentored them in aspects of the engineering project process, guided them technically when requested, and helped facilitate the work and resolve conflicts.

We had two specific manufacturing system oriented projects at Gonzaga that are described briefly below: designing a mass production line from membrane exchange assemblies (MEA) for PEM fuel cells and designing a transportable, self-contained food processing cell for cherry dehydrating.

\section{Fuel Cell Project ${ }^{5}$}

The goal of this project was to commercialize and scale-up a laboratory-based process to produce the membrane exchange assembly (MEA) portion of a polymer exchange membrane (PEM) fuel cell. The MEA is comprised of two electrodes that are pressed and bonded on to both sides of a Nafion membrane 3-10 mils thick (Figure 2). The electrodes are made by bonding a mixture of particulate carbon supported platinum and Teflon on to carbon paper (Toray paper). The Toray paper also has to be prepped with electrolyte and binder solution. Care must be taken at all times to limit the exposure of the electrodes to air to prevent possible contamination.

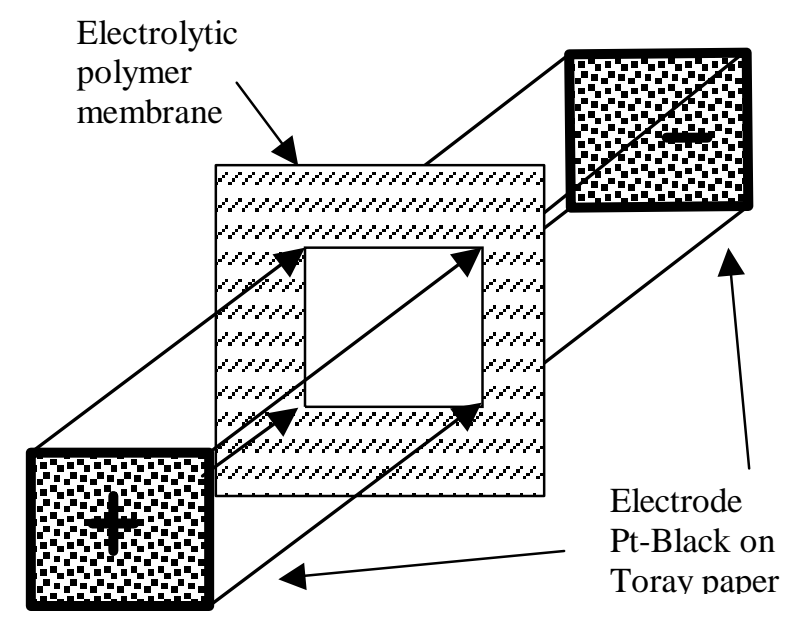

Figure 2 MEA Construction

The students had observed and recorded a laboratory-based process for making the MEA at a rate of about six per day. Assuming a production of 1000 2-kW fuel cell stacks per year, a production rate of $200 \mathrm{MEAs}$ per day (eight-hour shifts) was required.

The students designed the system as three discontinuous process modules that produced batches of sequentially assembled components (Figure 3): Toray Paper Pretreat, Electrode Fabrication, and MEA Assembly. Three independent lines allowed the system to meet the constraints of the eight-hour shifts and the long baking time, and facilitated quality checks of each component before it was assembled into the next higher component. It is costly to disassemble the stack and replace the MEA once it is produced, assembled, and pressed into a stack. 
The students simulated the processes and activity times with a discrete event modeling and simulation tool called SimProcess ${ }^{6}$. They experimented with capacities and times, working backwards from the 200 MEAs per day desired throughput, to determine the required process times and equipment capacities. They used this information to develop process and operation specifications (proprietary), to design and specify equipment such as ovens, sprayers, presses, conveyors, racks, special tooling, and to design a $1500 \mathrm{ft}^{2}$ facility layout (Figure 4). An example of an equipment description is shown in Table 2. The students also designed equipment to support manufacturing: a sheet handling support, a cutter alignment jig, and an electrode/press alignment jig. Detailed instructions for the use of the specific equipment and system were prepared for each production module.

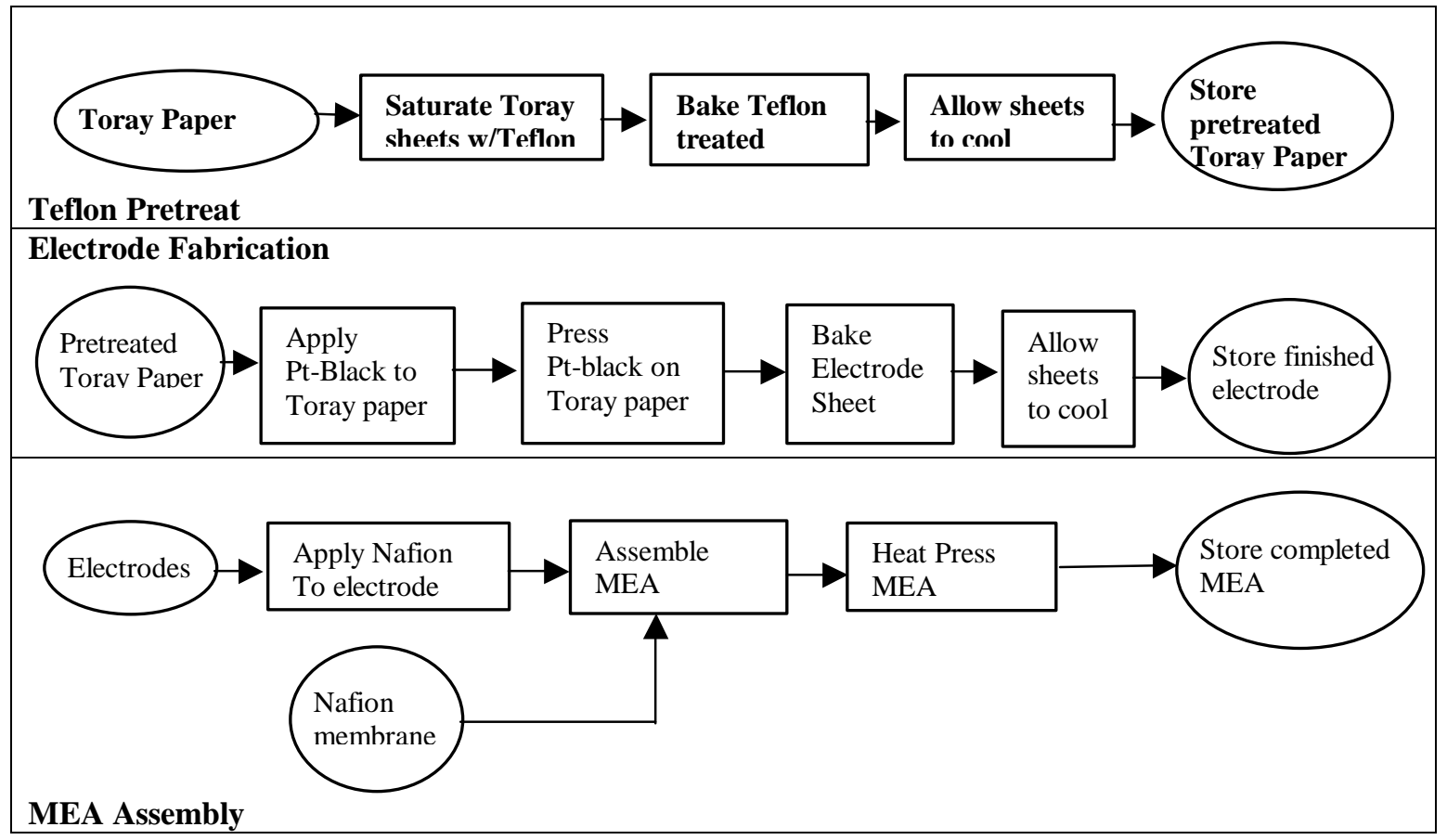

Figure 3 Proposed Process Breakdown

The students also used SimProcess' activity-based costing to find per unit labor, material, and utility costs for each production module as well as the total MEA unit cost. These costs were combined with the capital costs, obtained from the equipment and parts suppliers, and an estimated selling price (considerably lower than the cost of the laboratory-based process) to perform an economic analysis. The analysis showed an after-tax ROI of over 30 percent based on producing 50,000 MEAs per year.

The students developed a systems perspective, which is not taught in most of their Mechanical Engineering courses, and learned about the interfacing and integration that is key to manufacturing systems. They combined theoretical engineering education; exposure to fuel cell, design, and fabrication; economic analysis; project planning, management, communication skills; and learning to use tools (discrete event simulation) to achieve their results. 


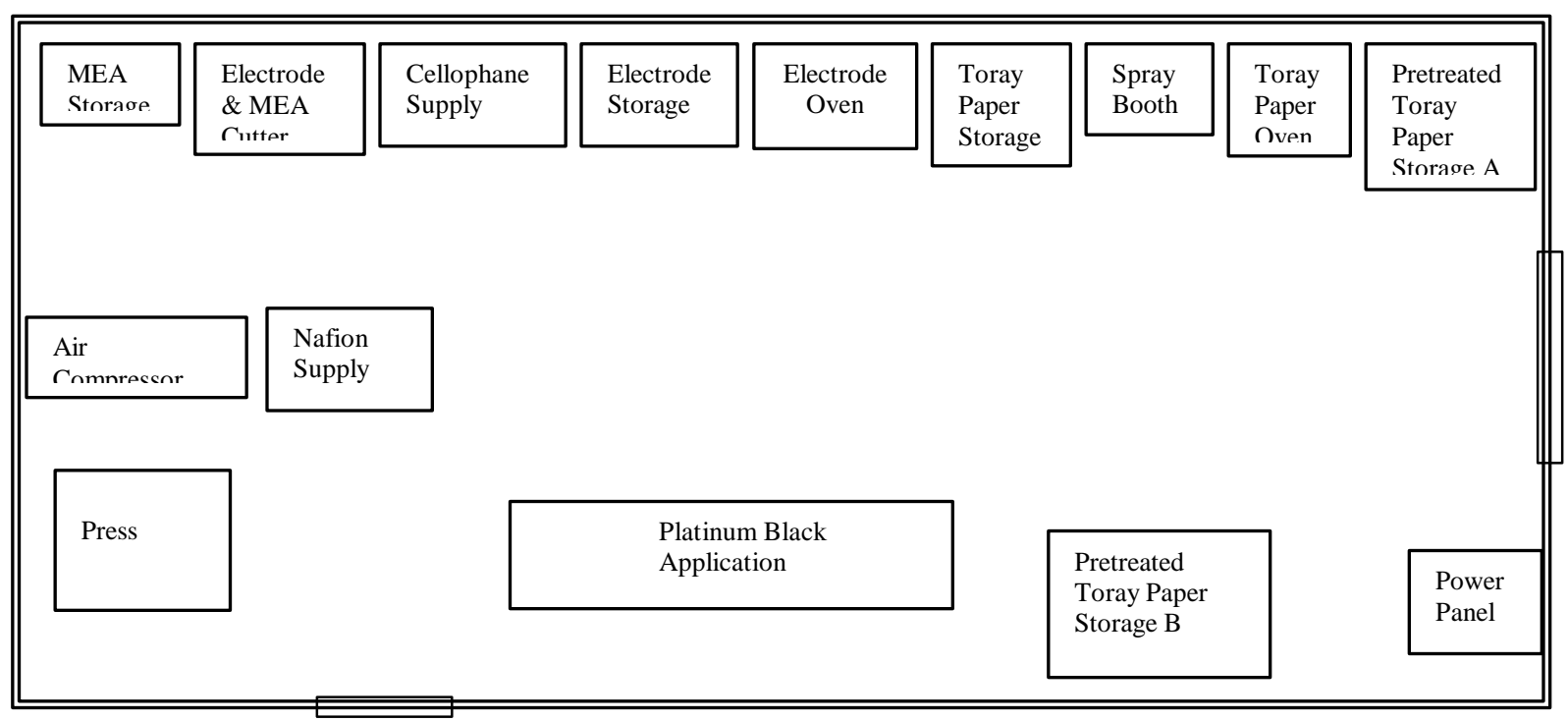

Figure 4 MEA Production Facility Layout

\begin{tabular}{|l|l|}
\hline Equipment type: & Automatic spray conveyor \\
\hline Process: & Platinum black application \\
\hline Manufacturer: & Paasche \\
\hline Machine: & F89-Sl-22(modified) \& 4 A-BUF-4 spray heads \\
\hline Price: & $\$ 35,000$ \\
\hline Utilities: & $1.5 \mathrm{~kW}, 24 \mathrm{cfm}($ air) @ 35psi \\
\hline Operators: & $1 / 2$ \\
\hline
\end{tabular}

Table 2 Equipment Description

\section{Flexible Materials Handling System Project ${ }^{7}$}

The second manufacturing systems project was to analyze the feasibility of a small-scale, transportable food processing plant using cellular manufacturing concepts. A cherry dehydration line that could handle the harvest from a three to four acre orchard was chosen for demonstration. The line was designed to fit into standard shipping containers (process cells) to deploy into orchards or crop fields. It was also designed to minimize the need for storage and handling of the cherries before processing to avoid damage and/or spoilage. The students used the same engineering process and project-planning sheet described previously.

One of the most challenging aspects of this project involved layout within the physical constraints of the container cells and the operations requirements. The students learned about shipping containers and about cherry processing equipment. They analyzed the containers for structural and spatial feasibility. The students developed the process, and identified and specified the required equipment and associated utility services. Key design issues were how to distribute the line among the cells and how to configure the cells to result in an efficient process. The students used SimProcess simulation to help them design the process and determine operation times, equipment capacities, staffing, operating costs, and process flow to maximize throughput within the constraints. The process flow from the simulation model is shown below in Figure 5 . 
The student decided to use four container cells to destem, sort, wash, and shake; to pit, dice, and blanch; to dry; and to pack and store the cherries. A fifth utility plant container cell was also needed. Figure 6 shows the configuration. The students considered operational needs, utility services, and human factors in laying out the equipment within the cells.

Flow using down time from $10: 30 \mathrm{pm}$ to $8 \mathrm{am}$ (8hr loading/ $16 \mathrm{hr}$ dayg)

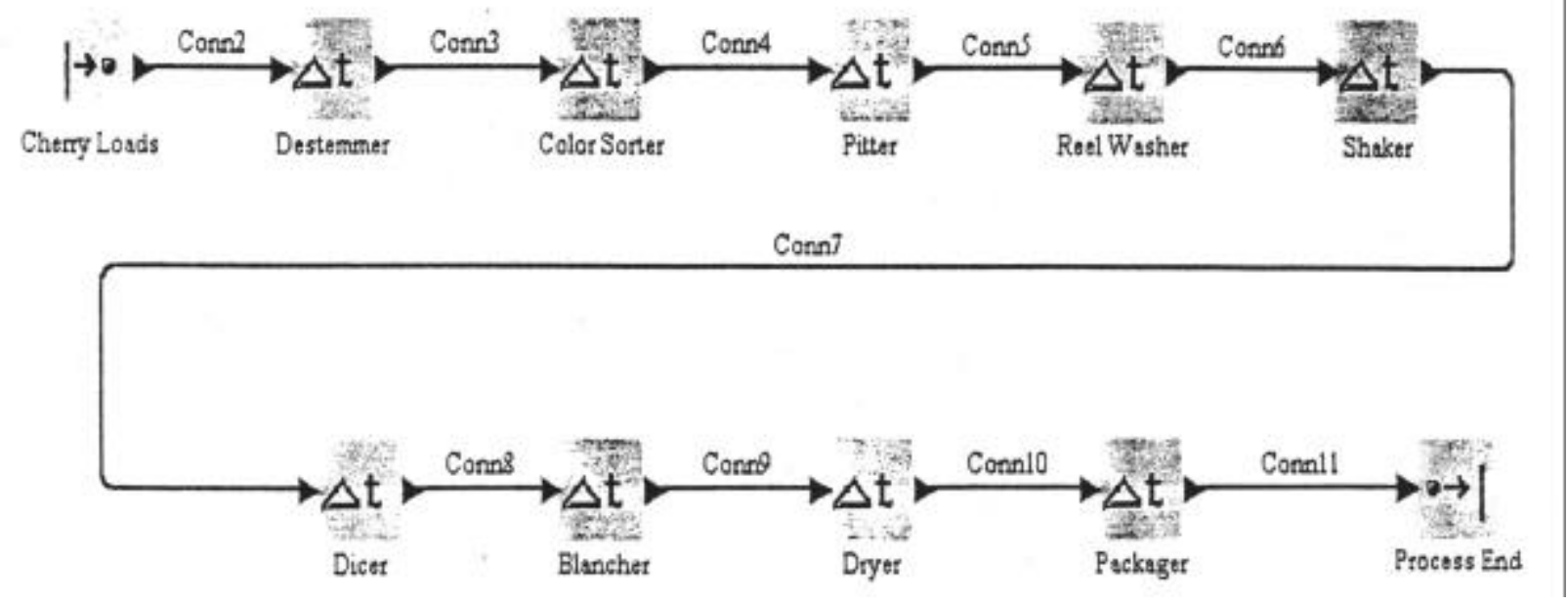

Figure 5 Process Flow from Simprocess
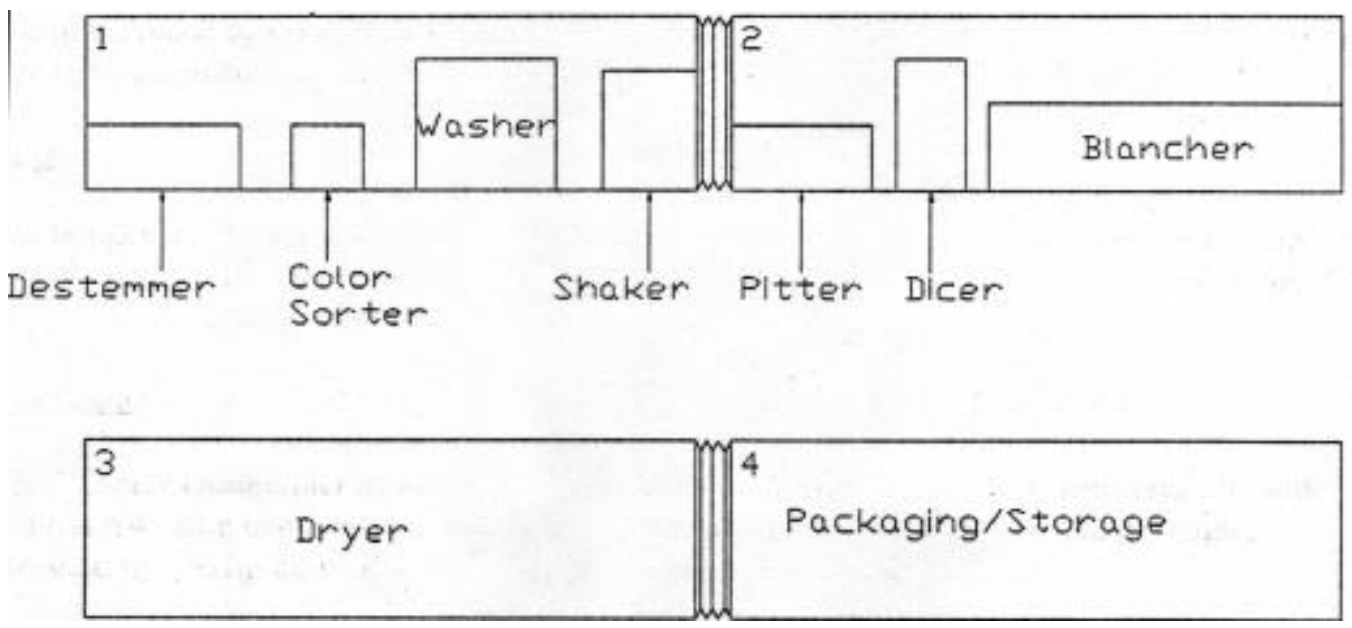

Figure 6 Shipping Container Cell Layouts

In executing this project, the students learned how to perform many of the same tasks required of a project engineer in a professional work environment. They developed designs whose overriding considerations were costs and operational efficiency, and worked with vendors to select economical and specific equipment (see example of similar equipment description in Table 4). Working with a commercial supplier, they had to designed a dryer/dehydrator, as none existed for this application. They performed an economic analysis of their proposal, and provided a report and presentation to the sponsor, who was very satisfied with the results. 


\section{Conclusion}

The approaches described in this paper introduced students to manufacturing and to engineering work methods relevant to the SME Manufacturing Competencies. The students were reminded that their work as engineers would be used to eventually manufacture something real. This demands attention to and development of detail that seems mundane to students in an academic setting. Students learned that planning for manufacturing is part of the design process, not a separate step independent of design. They also learned that manufacturing requires planning and consideration of a wide range of factors that have to be integrated and weighted against one another to accomplish the final objective of an acceptable finished product. Finally, we hope they learned that the cost of producing a part or product is a significant, often the most significant, factor in deciding among alternative designs.

Students learned structured methodologies and processes for creative work such as engineering design. They learned the techniques and importance of communicating technical information through formal engineering documentation and activities such as requirement specifications, design specifications, preliminary and critical design reviews, and status and activity reporting. The students also learned systematic planning and scheduling of work. Many of the projects were assigned early in the semester or at midterm, and the students were expected to execute those projects throughout the semester to produce the required deliverables. Another important lesson for the students was the benefit of generating as many alternatives as possible, then using formal processes to evaluate those alternatives.

Overall, the students learned a great deal about manufacturing while developing some of the competencies they were not usually exposed to in traditional Mechanical Engineering courses. Most of the students understood that the techniques and competencies they were learning would be necessary in the professional work environment. A lack of textbooks that combined the presentation of technical material with teaching of competency related engineering processes and practices was a significant difficulty. It required the coordination and timing of the presentation of fundamental technical material with engineering process material. Based on hearing the remarks of the students and from seeing their capstone projects, these students were better prepared, in both technical knowledge and professional arts, for their future careers.

\section{References}

1 Manufacturing Education Plan: Phase I Report in Manufacturing for the $21^{\text {st }}$ Century, Volume IV (1997), Society of Manufacturing Engineers, Dearborn, MI, USA.

2 Sule, D.R. (1994), Manufacturing Facilities Location, Planning, and Design, PWS Publishing Company, Boston, USA.

3 Belofsky, H. (1995), Plastics: Product Design and Process Engineering, Society of Plastics Engineers, Hanser/Gardner Publications, Inc., Cincinnati, OH, USA.

4 Dixon, John and Poli, Colorado (1995), Engineering Design and Design for Manufacture, Field Stone Publishers, Conway, MA, USA. 

University, Spokane, WA, USA.

6 Simprocess, CACI Corporation, San Diego, CA, USA.

7 Boroff, S., Higginson, J., Williamson (1998), Final Report for Flexible Materials Handling System, Gonzaga University, Spokane, WA, USA.

DOUGLAS L. RAMERS, Ph.D., PE. Assistant Professor, UNC Charlotte (1999 -), Gonzaga University (1995 1999), 18 years of industrial experience as engineer and engineering manager in aerospace, food, mining, chemicals, and family products industries. Interests in design processes, PEM fuel cells, AI and soft computing, remote sensing. North Carolina State University (PhD), Southern Illinois University-Edwardsville (MBA), Georgia Tech (BME). 